\title{
Rhinosinusitis in autologous and allogeneic bone marrow transplantation: a retrospective study on the performance of imaging studies on severity and prognostic evaluation
}

\author{
Rinossinusite em transplante de células-tronco hematopoéticas autólogo e alogênico: um estudo \\ retrospectivo sobre o desempenho de estudos de imagem na avaliação de severidade e prognóstico
}

Leo Sekine

Denise Manica ${ }^{2}$

Otávio B. Piltcher ${ }^{3}$

Camila J. Lopes ${ }^{4}$

Majoriê M. Segatto ${ }^{4}$

Alessandra A. Paz

Lúcia M. R. Silla

\begin{abstract}
The objective of this work was to evaluate the diagnostic and prognostic performance of a traditional imaging staging system for rhinosinusitis in the bone marrow transplantation (BMT) scenario. A retrospective cohort study was carried out at a bone marrow transplantation referral center involving subjects who underwent allogeneic or autologous BMT from September $1^{\text {st }} 2005$ to September $31^{\text {st }} 2007$ and later evolved with rhinosinusitis during the BMT inpatient period. Patients who had a previous history of sinusal disease or otolaryngologic surgery were excluded from the study. Data concerning mortality, the treatment of rhinosinusitis and BMT outcomes were extracted from medical files. The collected parameters were compared to the LundMackay tomographic staging system score which was calculated based on available tomography films of each patient. A total of 85 BMT were performed and 23 allogeneic and 14 autologous (43.5\%) BMT patients evolved with rhinosinusitis during transplantation. A significant association with LMS was found for the absolute neutrophil count (ANC), with a higher ANC (>500/mm3) correlating with a higher LMS (Mean LMS for lower ANC 6.08 and higher ANC 9.71 points, $p<0.05)$. Need for surgical management and post-BMT admissions, the resolution of the rhinosinusitis and overall mortality had no significant correlation with LMS. Patients with less than 500 neutrophils/ mm 3 are known to be prone to more severe infections, but paradoxically showed lower LMS when developing rhinosinusitis. However, there were no differences in the main outcomes between those with higher and lower LMS. This would possibly lead to an equivocal assumption of a less severe disease. Severely neutropenic patients are probably not able to mount an effective inflammatory response capable of inducing significant tomographic abnormalities. So, this imaging study would not be able to adequately evaluate the extent of sinusal involvement. We thus conclude that LMS is not an adequate staging system to evaluate the severity of BMT sinusal disease. Rev. Bras. Hematol. Hemoter.
\end{abstract}

Key words: Sinusitis; bone marrow transplantation; tomography; diagonoses; prognoses.

\footnotetext{
${ }^{T}$ Hematologista e hemoterapeuta. Médico contratado do Serviço de Hemoterapia do Hospital de Clínicas de Porto Alegre (HCPA). Hematologista do corpo clínico do Hospital Mãe de Deus.

${ }_{3}^{2}$ Otorrinolaringologista do corpo clínico do Hospital Mãe de Deus.

${ }^{3}$ Otorrinolaringologista. Médico contratado do Serviço de Otorrinolaringologia do HCPA.

${ }_{5}^{4}$ Médica.

${ }^{5}$ Hematologista e hemoterapeuta. Médica contratada do Serviço de Hematologia Clínica e Transplante de Medula Óssea do HCPA.

${ }^{6}$ Professora Adjunta da Faculdade de Medicina da Universidade Federal do Rio Grande do Sul; Professora do Curso de Pós-Graduação em Medicina: Ciências da Saúde/UFRGS; Chefe do Laboratório de Cultura Celular e Análise Molecular de Células Hematopoéticas do Centro de Pesquisa Clínica/HCPA.
}

Hospital de Clínicas de Porto Alegre-RS

Correspondence: Leo Sekine

Rua São Manoel, $543-2^{\circ}$ Andar

90620-110 - Porto Alegre-RS - Brasil

E-mail: leosekine@hotmail.com 


\section{Introduction}

Bone marrow transplantation (BMT) is a complex therapeutic procedure where a high level of chemotherapeutic-induced immunosuppression leads to a prolonged and intense vulnerability to infectious diseases. Apart from myelotoxicity in the allogeneic setting, there is also the immunocompromise imposed to prevent the development of graft-versus-host disease (GVHD). All of these characteristics contribute to high infection-driven morbidity and mortality rates that eventually delayed, to a great extent, developments in BMT during the last few decades.

A not uncommon infectious disease during BMT is rhinosinusitis, both in its acute and chronic forms. Of major concern, fungal rhinosinusitis, a form of invasive fungal disease, carries a very worrisome mortality rate, which exceeds $90 \%$ in some settings. Early diagnosis and treatment can potentially help improve the response to therapy but in many cases, due to the high level of immunosuppression and neutropenia, clinical signs and symptoms are scarce at the beginning of infection. Furthermore, there are few data on the use of imaging studies as diagnostic and prognostic staging tools in this particular subgroup of immunocompromised patients.

Currently, there are numerous tomographic staging systems designed for the evaluation of the severity and extent of rhinosinusitis in immunocompetent subjects, in particular those with chronic disease. Many have also proved to be of prognostic value. Among those, the most widely used is the Lund-Mackay staging system. This well known tomography score owes its popularity to a user-friendly interface and high inter- and intra-observer reproducibility. ${ }^{1,2}$ For this reason, it was highly recommended to be used in research by the Task Force on Rhinosinusitis. ${ }^{3}$ It was first described in 1993,4 and was divided in three different sections: a symptoms score, an endoscopic score and a tomography score. The latter is, by far, the most popular. The score ranges from 0 to 24 and mainly considers the degree of opacification of paranasal sinuses and the integrity of the ostiomeatal complex (Table 1). Some variations were later published, but the original score is still traditionally used in the otolaryngologic routine.${ }^{5,6}$ Despite its widespread use in the medical practice, there are only a few studies reporting its performance in immunocompromised patients, especially in the bone marrow transplantation (BMT) scenario.

The reported prevalence of rhinosinusitis during BMT ranges from $30 \%$ to $51 \% .7,8,9$ The degree of the tomographic abnormalities before BMT seems to correlate with the incidence of rhinosinusitis and its complications afterwards. 9 As cited above, rhinosinusitis during BMT has a great impact on morbidity and mortality, especially when fungal rhinosinusitis is involved. This specific type of rhinosinusitis has an incidence of $1.7 \%$ and a reported mortality of $62 \%$, even after the nadir of conditioning (period of profound
Table 1. Lund Mackay Staging System

\begin{tabular}{lll}
\hline Sinus System & Left & Right \\
\hline Maxillary & $0-2$ & $0-2$ \\
Anterior Ethmoidal & $0-2$ & $0-2$ \\
Posterior Ethmoidal & $0-2$ & $0-2$ \\
Sphenoidal & $0-2$ & $0-2$ \\
Frontal & $0-2$ & $0-2$ \\
Ostiomeatal complex & 0 or 2 & 0 or 2 \\
Total points for each side & $0-24$ & $0-24$
\end{tabular}

Scoring: For all sinus systems: $0=$ no abnormalities,

1 = partial opacification, 2 = total opacification.

For the ostiomeatal complex: $0=$ not occluded, $2=$ occluded

neutropenia) has ended.10 Among this subtype of rhinosinusitis, the invasive aspergillosis is still the most prevalent type of infection.

Thus, rhinosinusitis is a common and potentially fatal complication of BMT and an accurate imaging method for its evaluation and measurement is of great interest to both hematologists and otolaryngologists. With this in mind, the present study was designed to evaluate the performance of the Lund-Mackay staging system in evaluating the severity and predicting prognostic impact of rhinosinusitis in a BMT scenario.

\section{Patients and Method}

A 2-year retrospective review of patients who had undergone both autologous and allogeneic BMT was carried out in our institution. The cohort considered the clinical diagnoses of rhinosinusitis made by an otolaryngologist based on patient history, physical exam (including endoscopic examination) and sinusal tomographic studies. Clinical diagnosis of rhinosinusitis was established when two or more of the following were present: nasal obstruction, nasal discharge, facial pain or pressure and olfactory loss or reduction. Endoscopic diagnosis was based on one or more of the following findings: polyposis, purulent discharge from the meatus media and obstructive edema of the mucosa of the meatus media. Imaging studies were considered diagnostic when alterations of the ostiomeatal complex or paranasal sinus mucosa were found on tomographic films. 11 Three patients in this cohort had no imaging studies so the diagnosis was made only on clinical grounds and endoscopic findings. Patients were excluded if they had had a prior history of chronic rhinosinusitis before BMT or had undergone otolaryngologic surgery previous to the BMT.

The study period started on September $1^{\text {st }} 2005$ and finished on September $31^{\text {st }} 2007$. All the clinical data was extracted from medical files in our institution's medical archives. All available tomographic films were reviewed by an otolaryngologist from our department (Piltcher OB) who was unaware of the patient's identity and was responsible for calculating the Lund-Mackay staging system scores. 
Demographic characteristics, disease, conditioning and BMT data, tomographic abnormalities, clinical features of rhinosinusitis and its chronological correlation with the BMT period, major outcomes (survival and resolution of rhinosinusitis), clinical and/or surgical management, number of post-BMT hospital admissions, degree of immunosuppression (as measured by the absolute neutrophil count, with less than $500 / \mathrm{mm}^{3}$ meaning a higher level of immunocrompromise) and microbiological data were recorded. This research project was approved by the Research Ethics Committee of our institution.

\section{Statistical Analysis}

The data management and all the analyses were carried out using the SPSS 14.0 statistics program. The Fischer exact Test was utilized for the analysis of outcomes related to the Lund-Mackay score. Comparisons between types of BMT were achieved with the Student T Test. The Spearman correlation coefficient was used to compare the Lund-Mackay score with the number of post-BMT admissions. Finally, the Pearson's chi-square test was used to analyze the relationship of rhinosinusitis with mortality. A significant p-value was considered to be less than 0.05 .

\section{Results}

A total of eighty-five autologous and allogeneic BMT were performed at our institution during the 2-year period of the study. Thirty-seven patients (44\%) developed rhinosinusitis based on the diagnostic criteria cited above (23 allogeneic and 14 autologous). Hence, almost two thirds of those who developed rhinosinusitis were from the allogeneic group. The two most common indications for BMT were AML and ALL, representing almost half of the study cohort. Baseline characteristics of all patients enrolled in the study can be seen in Table 2 .

\section{Differences related to the type of BMT (Autologous $x$ Allogeneic)}

The mean Lund-Mackay score for the allogeneic group was 9.17 points $(\mathrm{SD}=5.31)$ and for the autologous group, the mean score was 6.23 points $(\mathrm{SD}=3.08)$. Although this difference was not statistically significant $(\mathrm{p}=0.077)$, there is a trend towards a higher score in the allogeneic group. Also, there was a trend towards a higher absolute neutrophil count (ANC) at diagnosis of rhinosinusitis in the allogeneic group (ANC $>500 / \mathrm{mm}^{3}$ : allogeneic $77.3 \% \mathrm{x}$ autologous $36.4 \%$, $\mathrm{p}=0.052$ ). This group also seemed to evolve with rhinosinusitis somewhat later (126.61 days from BMT) than the autologous group (76.17 days from BMT) although this difference was again statistically insignificant $(p=0.692)$. Interestingly, the amount of stem cells infused during BMT
Table 2. Baseline data

\begin{tabular}{|c|c|}
\hline Characteristics & $n=37$ \\
\hline Age (Mean $\pm S D$ ) in years & $\begin{array}{c}30,2( \pm 18,7) \\
\text { Range: } 3 \text { to } 65 \text { years }\end{array}$ \\
\hline $\begin{array}{l}\text { Sex } \\
\text { Male }\end{array}$ & $25(67,6 \%)$ \\
\hline $\begin{array}{l}\text { Race } \\
\text { Black } \\
\text { White } \\
\text { Other }\end{array}$ & $\begin{array}{c}1(2,7 \%) \\
34(91,9 \%) \\
2(5,4 \%)\end{array}$ \\
\hline $\begin{array}{l}\text { Patient Disease } \\
\text { ALL } \\
\text { AML } \\
\text { AMC } \\
\text { Aplastic Anemia } \\
\text { NHL } \\
\text { MM } \\
\text { Other }\end{array}$ & $\begin{array}{l}9(24,3 \%) \\
9(24,3 \%) \\
3(8,1 \%) \\
3(8,1 \%) \\
3(8,1 \%) \\
3(8,1 \%) \\
7(18,9 \%)\end{array}$ \\
\hline $\begin{array}{c}\text { Type of BMT } \\
\text { Allogeneic } \\
\text { Autologous }\end{array}$ & $\begin{array}{l}24(64,9 \%) \\
13(35,1 \%)\end{array}$ \\
\hline $\begin{array}{l}\text { Conditioning Regimen } \\
\text { BUCY } \\
\text { CY+TBI } \\
\text { Melfalan } \\
\text { BEAM } \\
\text { Other } \\
\text { Not available }\end{array}$ & $\begin{array}{c}11(29,7 \%) \\
4(10,8 \%) \\
4(10,8 \%) \\
3(8,1 \%) \\
9(24,3 \%) \\
6(16,2 \%)\end{array}$ \\
\hline GVHD (among Alogeneic BMT) & $11(29,7 \%)$ \\
\hline $\begin{array}{l}\text { Rhinosinusitis Diagnosis } \\
\text { Clinical } \\
\text { Radiologic } \\
\text { Both }\end{array}$ & $\begin{array}{c}3(8,1 \%) \\
14(37,8 \%) \\
20(54,1 \%)\end{array}$ \\
\hline Lund-Mackay Score (Mean \pm SD) & $8,1( \pm 4,8)$ \\
\hline $\begin{array}{l}\text { Rhinosinusitis Resolution } \\
\text { Yes } \\
\text { No } \\
\text { Not available }\end{array}$ & $\begin{array}{c}24(64,9 \%) \\
3(8,1 \%) \\
10(27 \%)\end{array}$ \\
\hline Overall Mortality & $13(35,1 \%)$ \\
\hline
\end{tabular}

was also significantly correlated with overall mortality in this study $\left(\mathrm{CD} 34<4 \times 10^{6} / \mathrm{kg} 50 \% \times \mathrm{CD} 34>4 \times 10^{6} / \mathrm{kg} 15 \%\right.$, $\mathrm{p}=0.049)$.

We found a high resolution rate for rhinosinusitis in the autologous group (92.3\%) but only half (50\%) of patients in the allogeneic group were cured with this difference being statistically significant $(\mathrm{p}=0.039)$. The resolution of rhinosinusitis was significantly correlated with death (nonresolution $100 \% \mathrm{x}$ resolution $16.7 \%, \mathrm{p}=0.003$ ). According to this finding, we also noted a significant increase in overall mortality in the allogeneic group (allogeneic 50\% x autologous $7.7 \%, \mathrm{p}=0.013$ ).

There were two diagnoses $(5.4 \%)$ of fungal rhinosinusitis in this cohort. No specific tomographic findings were predictive of this disease. These two patients underwent endoscopic examination with biopsy specimens showing 
invasive fungal disease. One of them was diagnosed with Rhizopus sp. and Aspergillus fumigatus was isolated in the other patient.

\section{The Lund-Mackay staging system score}

When comparing the level of neutropenia (characterized as ANC $<500 / \mathrm{mm}^{3}$ and ANC $>500 / \mathrm{mm}^{3}$ ), the group with less than 500 neutrophils $/ \mathrm{mm}^{3}$ at diagnosis of rhinosinusitis and, therefore, a greater degree of immunosuppression, had a lower score than the group with more than 500 neutrophils $/ \mathrm{mm}^{3}$ $($ mean $=6.08-\mathrm{SD}=3.26 \times$ mean $=9.71-\mathrm{SD}=5.39$ points, $\mathrm{p}=0.043)$. The degree of immunosuppression at this point was not correlated with mortality (ANC $>500: 57.1 \% \mathrm{x}$ ANC $<500: 66.7 \%$, $\mathrm{p}=0.719$ ).

We found no difference in the Lund-Mackay score for those who experienced resolution of rhinosinusitis and those who did not (resolution $6.96 \mathrm{x}$ non-resolution 10.00 points, $\mathrm{p}=0.201$ ). Also, there was no difference in the mean LundMackay score from those patients who survived the whole period of the study and those who did not (dead $8.92 \times$ alive $7.71, \mathrm{p}=0.472$ ).

Notably, the Lund-Mackay score for the group of patients who had another probable focus of inflammation that led to a suspicion of rhinosinus disease did not differ from those who had the diagnosis of rhinosinusitis as the main diagnostic hypothesis (a second focus $8.63 \mathrm{x}$ single focus 7.23 points, $p=0.409$ ). Patients who received antibiotics as the sole treatment for rhinosinusitis showed no difference in the Lund-Mackay score to those who also received surgical intervention (antibiotics 7.23 x surgical 9.25 points, $\mathrm{p}=0.354$ ). The Lund-Mackay score was not correlated with the number of post-BMT hospital admissions (Spearman correlation coefficient $=-0.058, p=0.733)$ and the presence of GVHD (GVHD 7.82 x non-GVHD 11.0, $\mathrm{p}=0.178$ ).]

\section{Discussion}

The group of patients studied was mainly composed of white male patients but included a wide range of age groups. The most common diagnoses were AML and ALL with a quarter of the population each.

Two thirds of BMT were allogeneic, reflecting the intense level of immunosuppression required by this type of BMT. At our institution, it is routine for BMT patients developing persistent fever of unknown origin to undergo computed tomography evaluations of paranasal sinuses and pulmonary parenchyma to investigate invasive fungal diseases. Therefore, the majority of patients with rhinosinusitis had accompanying imaging evaluations (91.9\%) which made a calculation of Lund-Mackay score possible. As shown in Table 2, the overall mortality rate was $35.1 \%$ which is comparable to the rates seen in other centers.
There were different patterns of clinical manifestations of rhinosinusitis between allogeneic and autologous BMT. Allogeneic BMT patients seem to develop rhinosinusitis somewhat later than autologous BMT patients, which might be a major contributor to the higher ANC seen at diagnosis. Moreover, the higher score observed in allogeneic BMT could possibly be a result of an increased immune response represented here as a higher ANC. As expected, autologous BMT had a higher level of resolution of the rhinosinusitis and consequently a lower mortality rate, which is potentially related to the lower degree of immunosuppression used in this type of BMT.

The Lund-Mackay score, in this cohort, seemed to be predominantly related to the degree of immunosuppression (ANC) as can be inferred from the lower score in the group of patients with less than 500 neutrophils $/ \mathrm{mm}^{3}$. Additionally, the group of patients with a higher score did not experience different outcomes from those with a lower score in respect to the resolution of rhinosinusitis, post-BMT hospital admissions, possibility of an extrasinusal infection focus, surgical intervention or overall mortality.

So, we conclude that in this cohort, the LundMackay score was not a good predictor of major outcomes, such as the resolution of rhinosinusitis or overall mortality, and was not even a good parameter for surgical intervention. It did not have the power to characterize populations with different levels of disease involvement. Consistently, higher Lund-Mackay scores were influenced by increased degrees of inflammation of the paranasal sinuses, which depends on the presence of competent neutrophils that, in larger numbers, would lead to a greater immune response. But the number of neutrophils and the amount of inflammation seems to be just an innocent bystander of immunosuppression and not a marker of the severity or prognosis of rhinosinusitis. In respect to outcomes such as mortality, the degree of opacification (measured by the Lund-Mackay system) is intuitively unlikely to be important in this context. Radiological signs of bone destruction or demineralization, complete opacification, involvement of soft tissue structures outside the sinuses, etc. are more likely to be of importance. These are not assessed by the Lund-Mackay system and are essential components of the rhinosinusitis radiographic evaluation for this specific group of patients.

The present study has some weaknesses inherent in its retrospective design. However, its publication is important as it gives some information on epidemiological data related to the subject and helps the formulation of some hypotheses. It will probably be of value to other researchers in order to design prospective trials. The results of this study need further confirmation, but they raise the question of how we should guide our practices in BMT patients evolving with rhinosinusitis if tomography abnormalities do not seem to be a good marker of disease extent or severity. It is possible that 
the elaboration of a specific score concerning other characteristics such as symptoms or endoscopic findings could lead to a better stratification and management of patients.

\section{Resumo}

O objetivo deste trabalho foi avaliar o desempenho diagnóstico e prognóstico de um escore de estadiamento de rinossinusite (RS) por tomografia em pacientes submetidos a transplante de medula óssea (TMO). Realizou-se um estudo de coorte retrospectivo de pacientes submetidos a transplante de medula óssea (autólogo e alogênico) de $1^{\circ}$ de setembro de 2005 a 31 de setembro de 2007 que desenvolveram $R S$ durante o periodo de internação do transplante. Pacientes com história prévia de doença sinusal ou cirurgia otorrinolaringológica foram excluídos do estudo. Dados relacionados à mortalidade, resolução da RS e desfechos do TMO foram extraídos do prontuário médico. Os parâmetros coletados foram correlacionados com o escore de estadiamento de Lund-Mackay (ELM), que foi calculado com base nas alterações tomográficas de cada paciente. Um total de 85 TMO foram realizados e 37 (23 alogênicos e 14 autólogos) destes pacientes desenvolveram $R S \mathrm{du}$ rante o transplante. Uma correlação significativa com o ELM foi encontrada quando se considerava a contagem absoluta de neutrófilos (CAN), com uma CAN mais alta $(>500 / \mathrm{mcl})$ se associando com um ELM de maior valor (média de escore para CAN baixa 6,08 e CAN alta 9,71 pontos, $p<0,05)$. A necessidade de intervenção cirúrgica e reinternações pós-TMO, resolução da $R S$ e mortalidade geral não mostraram correlação com o ELM. Mesmo assumindo que a neutropenia severa é um fator de risco relevante para intercorrências infecciosas durante o TMO, paradoxalmente, os pacientes com menos de 500 neutrófilos/mcl mostraram um ELM de menor severidade, embora não tenham evoluido de maneira diferente daqueles com maior ELM. É provável que ELM mais alto esteja simplesmente ligado ao fato de uma CAN mais alta levar a uma maior reação inflamatória e consequente alteração tomográfica. Desta forma, o ELM não parece útil na avaliação de pacientes altamente imunossuprimidos como os do TMO. Rev. Bras. Hematol. Hemoter.

Palavras-chave: Sinusite; transplante de medula óssea; tomografia; diagnóstico; prognóstico.

\section{References}

1. Oluwole M, Russell N, Tan L, Gardiner Q, White P. A comparison of computerized tomographic staging systems in chronic sinusitis. Clin Otolaryngol Allied Sci. 1996;21(1):91-5.

2. Hopkins C, Browne JP, Slack R, Lund V, Brown P. The LundMackay staging system for chronic rhinosinusitis: How is it used and what does it predict? Otolaryngol Head Neck Surg. 2007; 137(4):555-61

3. Report of the Rhinossinusitis Task Force Committee Meeting. Alexandria, Virginia. Otolaryngol Head Neck Surg. 1997:(3 Pt 2): S1-68.

4. Lund VJ, Mackay IS. Staging in rhinosinusitis. Rhinology. 1993; 31(4):183-4.

5. Lund VJ, Kennedy DW. Staging for rhinosinusitis. Otolaryngol Head Neck Surg. 1997;117(3 Pt 2):S35-40
6. Fokkens W, Lund V, Mullol J; European Position Paper on Rhinosinusitis and Nasal Polyps group. European position paper on rhinosinusitis and nasal polyps 2007. Rhinol Suppl. 2007;(20):1136.

7. Shibuya TY, Momin F, Abella E, Jacobs JR, Karanes C, Ratanatharathorn V. Sinus disease in the bone marrow transplant population: incidence, risk factors, and complications. Otolaryngol Head Neck Surg. 1995;113(6):705-11.

8. Ortiz E, Sakano E, Souza CA, et al. Chronic GVHD: predictive factor for rhinosinusitis in boné marrow transplantation. Rev Bras Otorrinolaringol. 2006;72(3):328-32.

9. Billings KR, Lowe LH, Aquino VM, Biavati MJ. Screening sinus CT scans in pediatric bone marrow transplant patients. Int J Pediatr Otorhinolaryngol. 2000;52(3):253-60.

10. Kennedy CA, Adams GL, Neglia JP, Giebink GS. Impact of surgical treatment on paranasal fungal infections in bone marrow transplant patients. Otolaryngol Head Neck Surg. 1997;116(6 Pt 1):610-6.

11. Diretrizes Brasileiras de Rinossinusites. Rev Bras Otorrinolaringol 2008;74(2) Suppl:1-59.

Avaliação: Editor e dois revisores externos

Conflito de interesse: sem conflito de interesse

Recebido: 28/03/2009

Aceito: 11/06/2009 